\title{
LEAVING DARWING BEHIND? TRANSCENDING BODY, MIND AND SOUL THROUGH THE OCCULT IN EDWARD BULWER-LYTTON'S A STRANGE
}

MARTA MIQUEL-BALDELLOU 1

Universidad de Lleida

\section{Resumen}

En la novela A Strange Story, concebida como un romance en defensa de lo sobrenatural, BulwerLytton aspira a conducir a su héroe Allen Fenwick hacia la creencia en la existencia del alma. BulwerLytton intenta redimir a Fenwick a través de la reducación espiritual, cuestionando así la teoría de la evolución de Darwin, publicada dos años antes que A Strange Story. Pese a todo, Bulwer-Lytton emplea la ciencia para analizar el alma. En el periodo victoriano, el siempre presente tema de la evolución del cuerpo humano como resultado de la selección natural de Darwin, la prevalencia de la mente como legado del periodo de la Ilustración y la posición problemática del alma como resultado del cuestionamiento de los preceptos cristianos son cuestiones tratadas y evaluadas en la novela de ideas de Bulwer-Lytton. El propósito de este artículo es analizar la forma en que los ideales victorianos respecto a la mente, el cuerpo y el alma son reflejados, a la par que transcendidos, a través de la utilización metafórica de lo oculto y el proceso de envejecimiento de sus personajes arquetípicos Palabras clave: la teoría de la evolución de Darwin; la fe cristiana; lo oculto; el cuerpo; la mente; el alma; envejecimiento; reeducación espiritual.

\begin{abstract}
In the novel A Strange Story, envisioned as a romance in favour of the supernatural, Bulwer-Lytton aims to conduct his hero Allen Fenwick toward the belief in the soul. Bulwer-Lytton attempts to redeem Fenwick through spiritual reeducation thus questioning Darwin's theory of evolution, published only two years before A Strange Story. Nevertheless, Bulwer-Lytton employs science to analyse the human soul. In Victorian times, the ever-present issue of the evolution of the human body as a result of Darwin's natural selection, the prevalence of the mind as a legacy of the Enlightenment
\end{abstract}

\footnotetext{
${ }^{1}$ Profesora de la Universidad de Lérida. Correo-e: mmiquel@dal.udl.cat. Recibido: 06-02-2009.
} 
period, and the troublesome position of the soul as a result of the questioning of Christian precepts are also tackled and evaluated in Bulwer-Lytton's novel. It is the aim of this article to analyse the way Victorian ideals of mind, body and soul are reflected and transcended by through both a metaphorical use of the occult and the archetypal characters' process of aging.

Key words: Darwin's theory of evolution; Christian faith; the occult; the body; the mind; the soul; aging; spiritual reeducation.

$\mathrm{F}$ radin (1961) contends Bulwer repeteadly believed in the work a novel could do (2). In this respect, Bulwer's novels represent a clear attempt to come to terms with the complexities of the Victorian world in which he lived, expressing a vivid sense of crisis; an awareness of the social changes and the scientific ideas that arose at the time. It is in this context that Bulwer defends the need to find a substitute for a lost faith; a desperate imperative to locate a moral centre that would return coherence to an increasingly fragmented perplexing modernity. Bulwer began his last artistic phase with his return to the metaphysical mode in A Strange Story, serialised in Dickens' All the Year Round from 1861 to 1862, as a quid pro quo once Bulwer had persuaded Dickens to alter the ending of Great Expectations.

The ruling idea presented in the novel was claimed to have originated from a dream; one Bulwer's son claimed to be even more interesting than the novel itself. The dream of a Victorian individual's faith in the soul in the midst of the awakening social upheaval as a result of Darwin's revolution. The Origin of Species made its impact as it raised questions fundamental to the life without making humankind the centre of its enquiry. It might be difficult to appreciate, at first glance, the ethical consequences when Darwin's The Origin of Species was followed by The Descent of Man, and the human being, the 'child of God' as it were, found himself not merely 'a little lower than the angels' but a member of the brute creation; an ape that had somehow developed an upright posture and a frontal cortex (Annan, 1966: 176-7). In this perspective, nature appeared as an inscrutable power while individuals and the whole destiny of the race sank to insignificance (Stevenson, 1960: 34); bringing 
conscience to a state of anaesthetic stupor, as Darwin himself was purported to have experienced in his personal life; a metamorphosis from his artistic phase to his scientific commitment (Campbell 1974).

That shift away from the centre was a silent and intense challenge to the Victorians' assumptions (Beer, 1998: ix). Contradictory beliefs arose in the society of the time, even though the aristocratic and middle-class male intelligentsia gathered around one single club, those of the respectable Victorians. Actually, as a focus for social gathering, the Athenaeum counted among its members men of letters like Charles Dickens, William Makepeace Thackeray, Anthony Trollope, Robert Browning, and Edward Bulwer-Lytton, while its scientific side was represented by Charles Darwin, Thomas Henry Huxley, and Herbert Spencer (Tucker, 2005: 214).

In the midst of this context, as Bulwer admitted to his friend John Forster, he remained hesitant about the public reception his new novel, A Strange Story, would receive. Through his correspondence with Dickens, Bulwer also mentioned the need to include an explanatory preface that would clarify the novel's main thesis. To that effect, Bulwer himself unravelled for the reader the images that composed his strange story:

Firstly, the image of sensuous, soulless Nature, such as the Materialist had conceived it; secondly, the image of the Intellect, obstinately separating all its inquiries from the belief in the spiritual essence and destiny of man $[\ldots]$ before it settles into the simple faith which unites the philosopher and the infant; and thirdly, the image of the erring but pure-thoughted visionary, seeking overmuch on this earth to separate soul from mind, till innocence itslef is led astray by a phantom. (Preface 8 )

In his preface, Bulwer also referred to the important changes Pierre Maine de Biran's ideas represented in the late $18^{\text {th }}$ century European thought. Maine de Biran was a disciple of Etienne Bonnot de Condillac and his doctrine of materialism. Aware of some phenomena inexplicable to the senses alone, de Biran embraced the concepts of free will and self-consciousness, thus uniting the mind to Condillac's reliance on mere matter. Nonetheless, as Campbell contends, de Biran felt something else was lacking, since not all phenomena could be elucidated through matter and mind. In 
this respect, he introduced the soul as a third element in the life of man. Accordingly, there were three orders of faculties which were held in harmony with each other: matter, mind, and soul. Taking these premises into consideration, Bulwer aimed to highlight the importance of the soul, of the spirit, through his recurrence to the supernatural. In A Strange Story, Bulwer sought to conduct his hero Allen Fenwick towards Maine de Biran's same goal as a student of philosophy: transcend the body and mind to acknowledge the life of the spirit. It has been contended that, through Fenwick's spiritual reeducation, Bulwer aimed to refute Darwin's theory of evolution "by employing science [...] to document the existence of the human soul and bolster Christianity's moral authority" (Campbell, 1986: 122).

Faithful to his often didactic aims, Bulwer provided an accurate explanation of the ideas each of the principal characters represented. Margrave, the villain, embodies the sensuous and souless Materialist. Fenwick, the hero, becomes the vivid image of the Intellect, separating his enquiries from the belief in the spiritual and resorting to material speculation before settling into faith. Lilian, the heroine, completes the tripartite nature of man, representing the soul as separate from the mind. As unequivocal representatives of the three aspects of the human being, these three characters in isolation are rendered incomplete by their refusal to resort to the rest of the elements that comprise man's inner nature.

The novel's hero is Allen Fenwick, a doctor-scientist who comes to town to practice medicine. As a disciple of Condillac and an acknowledged materialist philosopher, he constantly relies on common sense and dismisses anything which cannot be brought to a practical test. In the town, his materialistic views contrast with those of Dr Lloyd; an advocate of mesmerism and clairvoyance. It is implied that, due to Fenwick's materialism, Dr Lloyd is unable to be cured and dies as a result of Fenwick's inappropiate methods. Meanwhile, Fenwick falls in love with the innocent and spiritual Lilian, while a powerful and exotic man, Margrave, appears on stage to claim Lilian and engage Fenwick in his malicious purposes. Margrave is an adept to Eastern magic and identifies potential mediumistic powers in Lilian. Consequently, Margrave uses Lilian both to benefit from her own powers and to 
induce Fenwick to help him find the elixir of eternal life. Through his struggle with Margrave, symbolised through Lilian's recovery from her transient state, for the first time, Fenwick faces situations that defy his confidence in common sense and science. As a result, Fenwick realises his command of the mind is helpless in the face of Margrave's powers. Although Fenwick manages to steal Margrave's wand, thus depriving him of his youthful appearance, he is compelled to help Margrave perform the occult ritual to restore his youth. All in all, Fenwick manages to destroy Margrave, restoring Lilian to her former state and having won faith as a reward to his journey into the darkest aspects of life.

Throughout the novel, a world of esoteric symbols coexists with the provincial and hierarchical society of the town. These two aspects lead Fradin to claim Bulwer's novel points at an essentially social malady, attacking "the prevailing scientific materialism of the age" (1961: 5). After all, A Strange Story was published only two years after Darwin's Origin of Species, and Bulwer could not have possibly escaped its influence. According to Fradin, some of the melodramatic excesses portrayed through the novel must be the result of Bulwer's reaction to both Lamarck's and Darwin's evolutionary theories. Bulwer seems to be asking himself: "If man and the lower orders are linked by an unbroken evolutionary chain, can man have an eternal spark in him? [and] above all, among the blind processes of Nature, was there any room for God? And [if so], could this presumed purposeless will to progress be termed as a divine being" (Fradin, 1961: 5).

These questions are addressed in A Strange Story as Bulwer's novel attempts to reject evolutionary theory as the source of any final truth about man. These theories seem to be made explicit in one of the talks between Fenwick and his mentor, Dr Julius Faber. As the voice of reason, Faber discusses how reasoners of modern times, such as Lamarck, are led to ridiculous conclusions about the nature of man, following the path of science. Even though discussions that compare the animal with the human, there is an insistence on some spiritual essence in man. As Faber finally argues: "I take to be the proof of Soul in Man, not that he has a mind - because inferior animals have that, though in a lesser degree - but because he has the 
capacities to comprehend [...] the very truths not needed for self-conservation on earth" (Bulwer-Lytton, 2005: 360). Early on in the novel, Fenwick himself undergoes a trance in Dr Lloyd's museum whereby he seems to envision the ancient animals return to life. It is worth noticing Fenwick is only able to grasp this principle of life when he remains in a trance, that is, when his reason is suspended.

In sharp contrast to the rational Fenwick, Margrave embodies the sensuous soulless Nature of evolutionary theory. His life is an absorbing struggle for existence and instinct. He is presented as an amoral seeker of self-satisfaction and selfpreservation, and it is precisely through his character that Bulwer presents what he felt to be the unethical meaning derived from the Darwinian theory. And yet, as Fradin contends, Fenwick's mere reliance on the powers of reason and Lilian's sole spiritual presence, contrast with Margrave's dual nature, which render him one of Bulwer's most unforgettable characters. Margrave is presented as both exerting attraction and rejection on equal terms. His youthful appearance and charm are counteracted by his rejection of any society, which renders him an outsider. In this respect, Fradin defines him as "the familiar figure in 19th century fiction of the split personality" (9). His will to survive and defy the limits of time and his reliance on the powers of nature are appealing, and yet his methods are amoral. Thus, it is implied that life force without any moral purpose is necessarily deviant.

By contrast, Fenwick embodies the controlled conscious mind deprived from the life of the spirit. As opposed to Margrave, Fenwick indulges in social events and acquires certain popularity, especially through his initiation in society by Mrs Poyntz, who is in turn described as "the symbol of the weight of social convention and restraint, of the smothering force which society exerts on the individual" (Fradin, 1961: 11). And yet Fenwick's personality is not fully developed until he is confronted with his opposed nature, with Margrave. It is only through experiencing there is something else that meets the eye that his personality can come to full circle and unite with Lilian, that is, acknowledging the existence of the human soul in addition to that of the mind. While Margrave's amoral instinct for survival is destroyed, Fenwick's mind remains in as much as it is coupled with faith. All in all, each 
character embodies one sphere of human nature and lacks another. Margrave is instinct without reason; Fenwick is mind without faith; Lilian is spirit without reason; Mrs Poyntz is society without instinctual life. Only the interaction of the different spheres of human nature can render any individual's existence as complete.

Thus, in the microscosm of not so strange a story, Margrave arises as the amoral man, living by the dark light of evolutionary theory. In contrast, Fenwick arises as the ethical man, living by the light of the intellect. And yet, Fenwick is really brought to light when he abandons his defiant reliance on materialism; when he realises he can easily be mistaken by the senses. Gradually, through a process of selfdiscovery, Fenwick learns there is a higher sphere of reality that cannot possibly be apprehended by reason and science alone. In this sense, in a letter to Dickens, Bulwer further elaborated on these characters as types in a novel of ideas. Margrave, Bulwer contended, arises as the "sensuous material principle of Nature". Conversely, Fenwick, Bulwer claimed, "is the type of the intellect as divorced from the spiritual sphere". Refusing to believe in God, as a man of science and a convinced reasoner, Fenwick falls prey of his supreme reliance on the senses and his skepticism. Finally, Lilian, as Bulwer noted, exemplifies the soul as divorced from the intellect, and through her indulgence in mysticism she is in danger of losing her reason. Their isolated nature renders these three characters incomplete, and consequently, they are all in need of each other. Thus, it is finally contended that, only through the union of the three orders of man, human nature is made complete. As Bulwer notices in his letter to Dickens, Fenwick eventually must surrender to recognise the importance of the soul and God, thorugh his relentless devotion to Lilian. Similarly, she is brought back to life, and reason through her acknowledged love to Fenwick, that is, to her marriage to the world of the mind. Conversely, Margrave, as a mere materialist, is vanished from stage and, it is through the dismissal of a simple naturalistic approach to life that Bulwer demonstrates his affirmation of the Victorian ethics of body and mind, as culture, as opposed to the reliance on Nature, materialism, and the physical senses. 
Bulwer's choice of the supernatural and the romance to present his ideas unveils the importance to inquire into metaphysics and spiritualism, especially towards the end of his life. As Bulwer described in a letter to John Forster, dated on the $3^{\text {rd }}$ of December 1861:

What I really wish to imply is this [...] I want to intimate that [...] things yet more incredible than those which perplex Fenwick are related, and philosophers declining thoroughly to probe these marvels, they have been abandoned for the most part to persons who know little or nothing of philosophy or metaphysics. (qtd. by Campbell, 1986, 123)

Through A Strange Story, Bulwer sought to encourage philosophers to inquire into these marvels, into the spiritual and metaphysical sphere of life. In his letter to Forster, Bulwer firmly contended that "there must be a natural cause of them", thus affirming his belief in magic and its location in persons of peculiar temperament, as he advanced in his well-known story "The Haunted and the Haunters".

In this respect, A Strange Story can be considered a clear exponent of the supernatural in literature including instances such as: an elixir of life and immortality; mind control achieved with conjuring wands, mesmerism and clairvoyance, witchcraft and alchemy. And yet, unlike Zanoni, which is generally considered as a romantic novel supporting the ideal in art, A Strange Story draws attention to the metaphysical in an attempt to espouse a religious thesis. On this occasion, Bulwer seeks to combat materialism and Darwinism through the spiritual reeducation of the story's hero, Dr Allen Fenwick, who eventually acknowledges the existence and immortality of the human soul. Thus, Bulwer's A Strange Story makes use of both supernatural tapestry and a scientist hero to highlight the importance of the metaphysical sphere, that of faith and the soul.

At the beginning of the novel, Fenwick, a man of science, and Margrave's rival, is presented as a philosophical materialist, repudiating those who accept with credulity what cannot be explained through reason; this including any belief in God and the existence of the human soul. Thus, at first, Fenwick contends any knowledge we possess must be derived from nature. According to Bulwer, philosophers, represented by Fenwick, are guilty of intellectual presumption. In this respect, the 
novel underlies a bildungsroman plot: Fenwick finally discovers that man has a soul and that certain aspects of human life cannot be explained by reason alone. Thus, Bulwer points at science so as to support orthodox Christian beliefs. As Campbell contends, at the end of the novel, Fenwick admits Christianity as the only true faith and the Bible and prayer as the only path to find salvation. Through Fenwick's conversion, Bulwer provides evidence for the soul's existence, arguing that among animals only man possesses the capacity to conceive of God. In this sense, this special feature furnishes Bulwer's refutation of the Darwinian view of evolution.

The religious thesis exposed in A Strange Story, as a refusal to Darwin's overt reliance on natural selection as opposed to God's plot, echoes Victorian contemporary debates. These are also clearly present in the reviews of Bulwer's novel. The Eclectic Review praised A Strange Story as a reaffirmation of Christianity, and applauded Bulwer's so-called 'healthy change' in moral tone from his earlier novels. Conversely, the Saturday Review wondered why Bulwer had returned to the supernatural mode so many years after Zanoni, having succeeded with his domestic novels in the Caxton series. Nonetheless, as Conrad Christensen contends, Bulwer's last four novels prove "he had remained the idealist who had only very temporarily commisioned himself to be an accepter of realities" (184). As a whole, his later novels, including A Strange Story, are relevant to the realities and debates of the second half of the nineteenth-century, addressing the implications of Darwinian theories as well as materialist and scientific issues of the time. In his utopian novel, The Coming Race (1871), Bulwer envisioned a surviving race of the future as peaceful, but appallingly, materialistic. In Kenelm Chillingly, published in the year of his death, Bulwer advocated the need for individuals to dismiss the so-called 'motive-power', the force of the vril, in favour of humanity. Thus, Bulwer's critical ideas about materialism are already foretold in A Strange Story.

The least noble elements of humanity are revealed to be those of the fittest for survival, as the ever youthful and immortal Margrave illustrates. In clear analogy with Wilde's Dorian Gray, Margrave manages to divide himself from his soul and conscience, surviving through centuries by means of an elixir of life. The contextual 
supreme value conceded to the will to survive, to natural selection, to selfless power and vitality, that is, blind progress, is also represented through Margrave's materialistic will for life which has led him to destroy the soul in himself, and consequently, he is condemned. As a fake vampirical or Faustian figure, he has perfected his amoral will and has attained immortality. He is a worshipper of animal vitality, the fittest among the fit, capable of surpassing the normal life-span of man; a forerunner of Nietzsche's superman and embodiment of his life force.

In both A Strange Story and the utopian society he envisions in The Coming Race, Bulwer remains critical of the survival of either the individual or a society as a result of biological superiority, whereby the universe of ideas, as it were, plays no part. Through this materialistic conception of existence, any progress is rooted in the organic power of volition, as a result of nature's deterministic will to survive. Consequently, for Bulwer, Darwinian and socialist theories like Marxism, reinforced each other, that is, the psychical survival of the race demanded civilised altruism. Therefore, any individualities should remain subjected to the general will, or what Christensen defines as "a sympathetic consciousness of the common interest", which would eventually lead to Bulwer's much feared soul-destroying materialism. Bulwer, as a man of letters clutching to the past, felt the artist, the individual, was losing one of the main drives of creativity. Margrave attains immortality, but through his animalistic devotion to mere survival, dismissing the mind and the soul as domains of human existence. Conversely, Bulwer's eagerness for immortality depended on his creativity and the transcence of time though his mental efforts, and the Darwinian theory that future generations would inevitably replace the older and weaker representatives for the sake of survival, filled him with despair. Thus, in order to prevent such materialistic aims from settling in the social psyche, he sought to prove evidence of an inward existence; a metaphysical reality that would annihilate the absorbing tyranny of everyday life (Fradin 1961). As Conrad Christensen describes, Bulwer's final heroes are in search of discovering their soul, their personal integral ego, which would truly imply their rebirth into a higher state of development. This principle of self-identity emerges as the ideal counterpart of the vril, or rather, the virile life force. 
As Conrad Christensen argues, while expressing disaffection from the conditions of life in the Victorian period, Bulwer's A Strange Story also conveys his commitment to the principle of the individual soul (1976: 185). A woman naturally symbolises the soul in each of Bulwer's novel. The protagonists must strip away of the earthly portions of their personalities in order to pursue the quest of the soul. As a general rule, the male protagonists must undertake the dismissal of three earthly levels of identity: their physical animality, their civilised self as part of a family and a society, and their private intelligence. As Bulwer's letters to Dickens emphasise, $A$ Strange Story is to be "read as an allegory of conflicting forces within the human personality" (prologue).

In this sense, through a process of self-discovery, the young doctor Fenwick rejects three 'material' aspects of his identity to demonstrate his loyalty to the figure of the anima. In order to remain devoted to the chaste, and thus unearthly Lilian, he rebukes the traces that typify his amoral physical being -Margrave-, his civilised social identity- Mrs Poyntz-, and his rational and intellectual self - his late mentor and his former self-, that is, individual physique, social body and mind. In this respect, Lilian appears as the missing part of Fenwick's self, just as Margrave's acts as the darker aspect which he cannot admit to be his own. Lilian represents a saintly female metaphysical sphere; what Conrad Christensen defines as "a capacity that one can never fully know or realise in this life and for which there is no scientific evidence" (185), in other wods, the material embodiment of the human soul.

As one gathers from his letters and papers, through intuition, Bulwer himself perceived the existence of the soul so as to make life comprehensible, thus relying on his (ir) rational Victorian faith, despite the Darwinian debates of the time. Thus, it is implied that the truth of existence amalgamates the physical, the social, and the intellectual aspects of the personality. In this respect, the man who believes one of those selves constitutes his essence is inevitably doomed in the face of death.

Bulwer's strange story thus consists of the autobiography of Dr. Allen Fenwick, who has written an important medical treatise entitled "The Vital Principle: 
Its Waste and Supply". Echoing Bulwer himself, Fenwick writes himself into existence through his reason (Conrad Christensen). Fenwick had devoted his young existence to investigate the principle of life, which reappears as the Vril of The Coming Race in Bulwer's late utopian novel. This vital principle associates with men's volitional power, the will, which is defined as the basic energy of the physical universe, and when liberated, creates an effect that anticipates nuclear power. Through his endeavours, Fenwick encounters an individual, Margrave, that seems to possess, or rather, personify this vital principle. As a convinced rationalist, Fenwick gradually sees the need to inquire farther from the regions of science. Losing his initial determinist mentality, he enters strange and mystical realms which eventually lead him to engage in religious modes of thought. As a result of the death of his mentor and the discovery of these strange entities through Margrave's endeavours and Lilian's trances, Fenwick eventually abandons his orthodox medical research, identifying the vital principle as a spiritual, and therefore inescrutable, rather than a mere biological phenomenon.

Thus, A Strange Story presents an internal conflict linked to the unconcious, which is to say, it is linked with the occult, as any inquiry into the supernatural implies an inquiry into that which is hidden, the self. Discussions between Faber and Fenwick about dream states, hypnotism and telepathy, about phenomena that puzzle any scientific notion echo Bulwer's disquisitions about revealing truths. Bulwer admitted to Forster, Dickens and his own son Robert that he felt the need to believe "in the substance of what used to be called Magic", and yet, he constantly felt the increasing weight of scientific inquiries in the society of the time, which may deprive humankind of its essential qualities. In this respect, as Fradin contends, Bulwer felt something of the modern schizophrenia. At the core of his strange story, there is the idea that "man's experience in trance and dream may be as revealing as the daylight experience of the senses" (Fradin, 1961: 13). After all, Bulwer contended that strange phenomena are "dreams turned inside out"; spectral images being images-in-themind transposed externally and rendered visible. As opposed to Darwin's anaesthetics (Fleming 1961), Bulwer's aesthetic theory contends that it is in dreams that all human knowledge is inititated; thus establishing a link between dream 
visions and spectral images; the phantoms that come into being through the domain of art. In this respect, the importance placed on dreams and the unconscious images that flourish in the mind and are transposed, render Bulwer a forerunner of psychoanalysis and symbolism as far as his aesthetic theory is concerned. As Fradin admits, "Bulwer believed that in the art process there is a steady flow of reverie from the unconscious to the edge of consciousness [and it is] the task of the poet to capture and channel this reverie flow" (1961: 15). And yet his aesthetic theory also became a way of life; a firm commitment to higher spheres of life.

Due to states of illness, mainly exhaustion, brain fever and partial deafness, which often found some cure through hidrotherapy, Bulwer himself became concerned with the metaphysics of life and death toward the end of his existence. In this respect, as Christensen argues, Bulwer contemplated the approach of death in his relatively peaceful last years, while his conception of these metaphysical domain became even somewhat more Christian. As a whole, in the last years of his life, Bulwer devoted great attention to the church fathers and read widely in traditional works about prayer, the soul and the hereafter. And yet, as a paradoxically, or rather complementary issue, he remained a Rosicrucian; endowed with a somehow unorthodox fascination for spiritual manifestations. As a result of the general negative tone of the reviews, Bulwer wrote to his son that the public disliked mysticism and allegory, thus echoing his early fears that the audience would not understand the purpose of the novel he sought to present in his preface. Nonetheless, Bulwer still felt his 'strange' novel was also his highest work of fiction, as his grandson Victor admits in Bulwer's biography. A Strange Story, as one of Bulwer's last novels, addresses not only his deep commitment to aestheticism and his philosophy of life, but also epistemological debates affecting the Victorian psyche. After all, it was through his strange story, that also of his life, that Bulwer aimed to "restablish the intimate connection between the physical and the spiritual, thus recapturing the upper half of Darwin's great chain" (Fradin, 1961: 16). 


\section{BIBLIOGRAFÍA}

Annan, N., Ayer, A.J. et alii (Eds.) (1966): Ideas and Beliefs of the Victorians: An Historic Revaluation of the Victorian Age, New York, E. P. Dutton.

Beer, Gillian (1998): “Introduction” en Ch. Darwin (1859): vii-xxviii.

Bulwer-Lytton, Edward George (2004): A Strange Story, 1861-2, Doylestone, Wildside Press.

Campbell, J. L. (1986), Edward Bulwer-Lytton, Boston, Twayne.

Campbell, J. L. (1986): “Occult and Scientific Romaces," en Edward Bulwer-Lytton (1986): 109-127.

Campbell, J. A. “Nature, Religion and Emotional Response: A Reconsideration of Darwin's Affective Decline." Victorian Studies (December 1974): 159-174.

Christensen, A. C. (1976): Edward Bulwer-Lytton: The Fiction of New Regions, Athens, The University of Georgia Press.

Christensen, A.C. (2004): The Subverting Vision of Bulwer-Lytton: Bicentenary Reflections, Newark, University of Delaware Press.

Christensen, A.C. "Back to the Regions of Pure Forms: A Strange Story, The Coming Race, The Parisians, Kenelm Chillingly" in A.C. Christensen (ed.) Edward BulwerLytton: The Fiction of New Regions (1976): 170-209.

Christensen, A.C. "Writing and Unwriting in The Caxtons, My Novel, and A Strange Story", in A.C. Christensen (ed.), The Subverting Vision of Bulwer-Lytton: Bicentenary Reflections (2004): 200-211.

Darwin, Ch. The Origins of Species, Oxford, Oxford University Press.

Fleming, D. (1961): “Charles Darwin: The Anaesthetic Man”, Victorian Studies: 219236.

Fradin, J. I. (1961): “'The Absorbing Tyranny of Every-Day Life': Bulwer-Lytton's A Strange Story", Nineteenth-Century Fiction, 16.1: 1-16.

Stevenson, L. (1960): “Darwin and the Novel”, Nineteenth-Century Fiction, 15.1: 29-38.

Tucker, H. F. (Ed.) (2005): A Companion to Victorian Literature and Culture, Oxford, Blackwell. 